\title{
Mountain Legacy Announces Plans
}

\author{
Mountain Legacy announces plans for conference on Mountain Hazards \\ and Mountain Tourism, calls for nominations for second Hillary Medal, \\ and proposes research and development institute in Rolwaling
}

One year ago, fifty-five delegates representing 15 different nations from as far away as New Zealand, Canada, South Africa, and Sweden, converged on Sagarmatha National Park for an international symposium entitled "The Namche Conference: People, Park, and Mountain Ecotourism" (May 2426, 2003; Namche Bazar, 3350 m). The event was organized by United Nations University (UNU), Bridges: Projects in Rational Tourism Development (Bridges-PRTD), and HMG's Department of National Parks and Wildlife Conservation (DNPWC), and scheduled as part of the closing festivities marking the Mount Everest Golden Jubilee Celebration.

One of the 14 resolutions and recommendations of the Namche Conference was that a new association be established, to be called Mountain Legacy. Two immediate responsibilities were envisioned.

- First, Mountain Legacy would organize sequels to the Namche Conference - that is, international events bringing together academics, planners, commercial operators, agencies, grass roots organizations, and other stakeholders to confer with the host community in a remote mountain tourism destination. These events would be held every four years in Namche Bazaar, and every four years (at a two year off-set) in some other remote mountain tourism destination.

- Secondly, Mountain Legacy would be responsible for the presentation every two years, in the context of the Namche Conference, of the Sir Edmund
Hillary Mountain Legacy Medal "for remarkable service in the conservation of culture and nature in remote mountainous regions." (The first medal was awarded to Michael Schmitz and Helen Cawley, who for the past decade have been working on keystone cultural and ecological projects in Solu-Khumbu, including the Tengboche Monastery Development Plan, the Thubten Choling Monastery Development Project near Junbesi, and the Sacred Lands Initiative.)

In addition, Mountain Legacy would undertake other projects in support of tourism and volunteerism in remote mountainous destinations.

As of April 2004, Mountain Legacy is officially registered as an NGO (HMG Regd No. 1018/060-61). The board has following members:

- Arjun Adhikari - President

- Arjun Kafle - Vice-President

- Kumar P Mainali - General Secretary

- Laxman Karki - Joint Secretary

- Geetanjali Nanda - Treasurer

- Bharat B Shrestha and Ganesh P Bhattarai - Members

Anyone interested in joining Mountain Legacy, or in collaborating on any of the projects outlined below, should contact Arjun Adhikari Tel: 977-1-5528090, E-mail: editors@himjsci.com, adhikariu@yahoo.com

\section{Mountain Legacy Announcements}

1. From July 1 to December 31, 2004, Mountain Legacy will accept nominations for the second Sir
Edmund Hillary Mountain Legacy Medal. (See Web site: www.mountainlegacy.org)

2. The second Mountain Legacy Conference will focus on Rolwaling (Dolakha District, Nepal) and will be held in October 2005 . The theme will be "Mountain Hazards and Mountain Tourism.”

3. Mountain Legacy is now ready to begin planning for the Rolwaling Mountain Legacy Institute.

Prospective collaborators The concept and rationale for the RMLI are outlined below. (Revised from Vol 1 No 2)

\section{Rolwaling Mountain Legacy Institute}

Rolwaling Valley in north central Nepal presents an unusual combination of problems and opportunities linking cultural and natural conservation, tourism development, and scientific research.

Rolwaling's value as a biological sanctuary derives partly from its location and physical isolation. Running east-west for approximately $30 \mathrm{~km}$, it is separated from Tibet by a stretch of the Himalayas that includes GauriShankar (7134 m), which for some time was thought to be the highest peak in the world. The Rolwaling River flows into the Bhote Kosi (one of several rivers of the same name); this Bhote Kosi soon becomes the Tamba Kosi. Simigaon, at the confluence of the Rolwaling and the Bhote, is about $90 \mathrm{~km}$ east of Kathmandu, as the crow flies. It can be reached by a 4 or 5 day trek from Barabise, which lies on the 
A new NGO born out of the Namche Conference ("People, Park, and Mountain Ecotourism"; May 2003), Mountain Legacy has announced a conference focusing on Rolwaling Valley to be held in October 2005. The theme will be "Mountain hazards and mountain tourism." As of J uly 12004 , Mountain Legacy will be accepting nominations for the second "Sir Edmund Hillary Mountain Legacy Medal," to be awarded for remarkable service in the conservation of culture and nature in remote mountainous regions." Mountain Legacy is also planning to establish a research and development institute in Rolwaling Valley.

road to Tibet in the next valley to the west, or by a 2 or 3 day trek from Dolakha, the district administrative seat, located on a short branch off the Swiss road that connects Lamosangu with Jiri. The latter trail, the lower trails in Rolwaling itself, and particularly the steep ascent to Simigaon, are subject to frequent damage during the monsoon season, a problem that has recently been alleviated somewhat by improvements initiated by the Austrian INGO Eco Himal and by the Tsho Rolpa Glacial Lake Outburst Flood (GLOF) hazard mitigation project being carried out with Japanese and Dutch assistance. To the east of Rolwaling is Khumbu district, which in 1976 was gazetted as Sagarmatha National Park. The wall of peaks between Rolwaling and Khumbu is breached by the formidable Tashi Lapsta pass: with good weather, one can make the crossing between the last settlement in Rolwaling and the most westerly settlement on the Khumbu in about four days. Altogether, access to Rolwaling is not quite impossible, but definitely more inconvenient than the most popular trekking routes, several of which can now be approached by air.

Cultural factors have contributed to the conservation of species in Rolwaling. According to Tibetan Buddhism, about 1250 years ago Padmasambhava [aka Guru Urgyen Rinpoche] plowed the valley out of the mountains in order to serve as one of eight "beyul," refuges that were to remain hidden until, in a time of religious crisis, they would serve as sanctuaries, protecting dharma until the danger passed. The neighboring Khumbu was one such zone, and Rolwaling, in the shadow of the mountain abode of the goddess Tseringma (i.e.GauriShankar), was another. Unlike Khumbu, Rolwaling remained isolated and unimpacted until the nineteenth century, and then was visited by a very few wanderers and outcasts. Due to the limited amount of arable land and the unsuitability of this east-west valley as a trade route between Tibet and India, Rolwaling's inhabitants remained poor and few, but devoutly mindful of their spiritual heritage. The Buddhist bans on hunting and slaughter, elsewhere observed less scrupulously, have protected the fauna; even plants are considered living creatures which ought not to be harmed if possible.

A third general factor that has contributed to the relatively unimpacted state of Rolwaling Valley has been the government's limitation of tourist access. Until recently, you needed both a trekking peak permit and a regular trekking permit. The trekking peak permit involved costs and other factors that essentially excluded the possibility of independent trekking. All visitors arrived in self-contained tented caravans which contributed virtually nothing to the economy of Rolwaling villages. Therefore there has been very little development of infrastructure, and not much impact on the environment.

In terms of biodiversity, Rolwaling is worthy of close attention. Janice Sacherer estimated that there are approximately 300 different plant species (Sacherer 1977, 1979 ). The atypical east-west orientation of the valley creates conditions unlike those in any other valley of the Himalayas. Partially shielded by its southern wall from the monsoon, Rolwaling has characteristics of the dry inner Himalaya; a good part of the flora derives from the Tibetan steppe and, in Nepal, is more typical of eastern valleys. As in other Himalayan valleys, Rolwaling's ecosystems vary dramatically from the broad glaciated valleys to the chiseled fluvial channel downstream; to a much greater extent than in other valleys, the sharp contrast between north- and south-exposed slopes affects the distribution of species. The eastwest orientation of the valley also makes it a convenient corridor for mobile fauna. Rolwaling is visited by quite a few of the charismatic mammals, including wolves, fox, several species of goat, bear, jackal, langur, and several members of the cat family (including snow leopard). Every resident that we interviewed on the subject is convinced that yeti frequent the valley. In short, Rolwaling's biological assets are clearly worth studying; their conservation should also be accorded high priority as the valley's protective isolation breaks down.

Furthermore, one cannot consider development scenarios in the high Rolwaling Valley without assessing the implications for the rich subtropical ecosystems of the Tamba Valley into which it feeds. 
If isolation has had a benign effect on the natural ecosystem, the human residents of Rolwaling have observed the tourism boom with envy. In next door valleys, every family could throw open its doors to backpackers and cash in on the amenity values of their homeland; in Rolwaling, the stakeholders stare wistfully as organized trekking caravans deploy their tents by the river, cook up their burrito and quiche feasts, and buy nothing from the local residents. In Khumbu, their relatives enjoy the benefits of prosperity: schools, upscale monasteries, telephone, electricity, numerous clinics, a hospital, post office - even Internet, saunas, pool halls and chocolate croissants: none are available in Rolwaling. Many young men have found employment with trekking and climbing services. Such work entails extended absence from Rolwaling, and even emigration to Kathmandu or Khumbu. The result is a brain and manpower drain that leaves the villages of Rolwaling populated by women, children, and those no longer capable of strenuous labor. Agricultural fields have been abandoned, livestock ineffectively tended, trails poorly maintained. Alcohol, the only recreational option, is a serious health problem.

This disparity between the neighboring districts has created in Rolwaling (as in the access routes) an intense demand for free access to backpackers and economic opportunity. Several years ago, due to the threat of Maoist attacks, the police checkpost in Simigaon was removed. At this point, Rolwaling is officially open to general trekking, and, as the prospects for peace improve, the valley will become an important trekking destination.

\section{Research Opportunities}

At the western end of Rolwaling Valley, Tsho Rolpa, one of the largest and highest elevation lakes in the Himalayas, has been growing over the past decades due primarily to the recession of Trakarding Glacier. Attempts to mitigate the danger of a glacial lake outburst flood (GLOF) have included siphoning, installation of a warning system, and reduction of the lake level by 3 meters through an artificial drainage channel. Due to depletion of project funding, the drainage efforts have stopped far short of the recommended objective. Particularly as there is a real threat of a catastrophic GLOF, Tsho Rolpa is an appropriate place to begin long-term study of glacial melting, runoff hydrology, and moraine stability.

Rolwaling is also a good location for ecological research. Zonation is extremely compressed. The east-west orientation results in unusually sharp differences on the northward and southward facing slopes; it also means that the valley is probably an important wildlife corridor. Numerous ethnobotanical resources have been identified; now would be a good time to study them in the wild, and also to begin efforts to cultivate them as cash crops.

Serious anthropological studies by Sacherer and Baumgartner in the 1970s provide useful baseline data against which the current changes, especially the impact of tourism, can be measured and monitored. Specific studies that are urgently needed: the Rolwaling dialect of Sherpa, and Rolwaling traditions of song and dance.

\section{RMLI Format}

In the initial phase, RMLI is envisioned as an institute of opportunity rather than infrastructure. That is, researchers would use existing facilities (lodges and homes) rather than constructing new infrastructures. This would permit rapid initiation of programs, significant ongoing economic contribution to the village economy and minimization of impact on the object(s) of study.

The proposal calls for Mountain Legacy to assist researchers in recruiting volunteers. This would provide an opportunity for tourists to stay for prolonged periods, making contributions to research and practical projects, and also injecting expenditures for living expenses into the local economy. International students could be recruited either as study-abroad program participants or as interns. These students could either assist established researchers or design and implement their own programs consistent with the aims of the MLI.

The primary objective of RMLI would be to facilitate research and establish a database, while developing a special type of ecotourism in Rolwaling. RMLI would encourage long-term stays at very low per-diem rates, as opposed to so-called "quality tourism," which aims to extract the maximum profit over the course of short stays. It is expected that such an institute, well-publicized, would be a magnet not only for prospective participants but also for other tourists. Just as tourists go out of their way to visit cheesemaking factories, they would visit Rolwaling to see the world-famous research center and to contribute to whatever on-going projects might need their help.

Again, Mountain Legacy invites collaboration on all of its projects.

\section{Contact}

Arjun Adhikari

Tel: 977-1-5528090

E-mail: editors@himjsci.com adhikariu@yahoo.com

\section{References}

Sacherer J. 1977. The Sherpas of Rolwaling Valley, North Nepal: A Study in Cultural Ecology. Ecole Pratique des Haute Etudes (Paris): Doctoral dissertation [Unpub]

Sacherer J. 1979. The High Altitude Ethnobotany of the Rolwaling Sherpas. Contributions to Nepalese Studies, Vol VI, No 2. Kathmandu: CNAS, Tribhuvan University 